Int. J. Curr. Res. Med. Sci. (2018). 4(5): 45-50

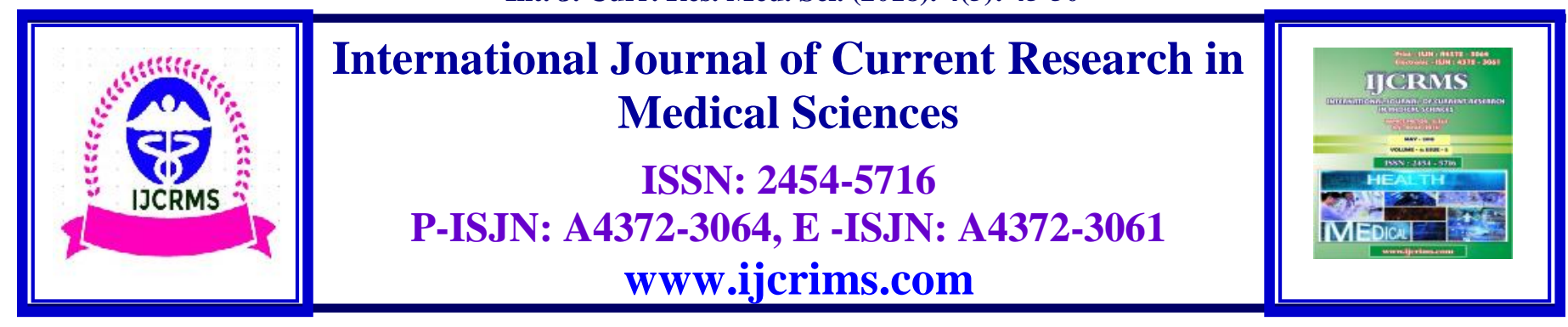

\title{
Effect of gonadotropins versus a selective estrogen receptor modulator on ovulation in anovulatory women.
}

\author{
Dalia Ibrahim MD, Mohamed Abdo MD, Nadia Abozied MD and \\ Hanan Ghoniem MD. \\ Department of Physiology, Pharmacology, Obstetrics and Gynecology, Suez Canal University.
}

\begin{abstract}
Background :

Anovulation and oligo-ovulation are ovulatory disorders that are estimated to cause $21 \%$ of female.

Over the past several years, new developments have occurred in ovulation induction therapy. These developments, which include new information relevant to established methods of inducing ovulation.

Pulsatile GnRH has been used with less success in WHO Group II anovulatory women. Clomiphene citrate and FSH are the agents of choice for ovulation induction therapy in Group II women.

FSH may be an appropriate first line treatment for some women with PCO and anovulatory infertility particulary older patients.

Aim of the study: This study was designed to compare the effect of starting with gonadotropins versus clomiphene citrate cc(selective estrogen receptor modulator) on ovulation in anovulatory women.

Material \&Methods:

a case-control study include 40 patients anovulatory(regular and irregular cycles) and want pregnancy attended to outpatient clinic in Suez Canal university hospital.

Two groups of patients anovulatory, group (1) 20 patients starting with cc in $2^{\text {nd }}$ day of cycle $100 \mathrm{mg}$ daily for 5 days then complete from $7^{\text {th }}$ day with FSH till dominant follicle DF $18 \mathrm{~mm}$ or more.

And group (2) 20 patients starting with FSH 75 IU in $2^{\text {rd }}$ day of cycle for 4 days then complete from $6^{\text {th }}$ day with cc till dominant follicle DF $18 \mathrm{~mm}$ or more. Folliculometry, Serum medluteal progesterone, E2, FSH and LH done for every patient

Results. In this study we found that ovulation rate was higher in G2 than in G1

Also early ovulation was significant in G2 than in G1

Conclusion. The results suggest that it is more effective to start with gonadotropins versus clomiphene citrate in anovulatory women on ovulation and as a cost effective regimen.
\end{abstract}

Keywords: clomiphene citrate, gonadotropins, ovulation. 


\section{Introduction}

Women who are concerned about their fertility should be asked about the frequency and regularity of their menstrual cycles. Women with regular monthly menstrual cycles should be informed that they are likely to be ovulating, Women who are undergoing investigations for infertility should be offered a blood test to measure serum progesterone in the mid-luteal phase of their cycle (day 21 of a 28 -day cycle) to confirm ovulation even if they have regular menstrual cycles (1).

Women with irregular menstrual cycles should be offered a blood test to measure serum gonadotrophins (follicle-stimulating hormone and luteinising hormone) (2).

The World Health Organization classifies disorders of ovulation into 3 groups: group I disorders are secondary to hypothalamic pituitary failure, They typically have amenorrhea and do not bleed in response to progestin challenge. This group of disorders is characterised by low gonadotrophins, normal prolactin and low oestrogen, and it accounts for about $10 \%$ of ovulatory disorders. Failed ovarian follicular development results in hypooestrogenic amenorrhoea in this group of disorders.(2).

group II disorders are a result of hypothalamic pituitary dysfunction, They typically experience oligomenorrhea, but they may have anovulatory cycles or amenorrhea with bleeding in response to a progestin challenge. Included in this group are women with polycystic ovary syndrome (PCOS).

This group, which is characterised by gonadotrophin disorder and normal oestrogen, accounts for about $85 \%$ of ovulatory disorders. This group of disorders results in anovulatory oligo/amenorrhea,predominately involving women with polycystic ovaries. Polycystic ovaries are present in about $80-90 \%$ of women with oligomenorrhoea and $30 \%$ of women with amenorrhoea.About $30 \%$ of the PCOS population is of normal weight. The new definition for the diagnosis of PCOS requires the presence at least two of the following three criteria: oligo- and/or anovulation, clinical and/or biochemical hyperandrogenism, polycystic ovaries(which is usually obtained from an ultrasound scan) requires the presence of at least 12 follicles measuring 2-9 $\mathrm{mm}$ in diameter, with the exclusion of other aetiologies.(3).

and group III disorders are secondary to ovarian failure. This group, which is characterised by high gonadotrophins with hypogonadism and low oestrogen, accounts for about $4-5 \%$ of ovulatory disorders (4).

The most useful indication for pulsatile GnRH therapy is functional hypothalamic amenorrhea (WHO Group I). In these patients, endogenous GnRH secretion is reduced.5,6,7.

Pulsatile GnRH has been used with less success in WHO Group II anovulatory women. 8,9 Clomiphene citrate and hMG are the agents of choice for ovulation induction therapy in Group II women;

FSH is a glycoprotein hormone of approximately $35 \mathrm{kD}$, synthesized and secreted by the pituitary gland. FSH is essential for follicular growth, oocyte maturation, and sex steroid hormone secretion from the ovary. The use of FSH is well established for the induction of ovulation in anovulatory women and for the induction of multiple oocyte development in preparation for various assisted reproductive technologies. Until the recent advent of recombinant FSH, gonadotropin preparations were available only from urinary sources. hMGs contain equal amounts of FSH and LH, whereas purified urinary preparations of FSH (urofollitropin or "pure" FSH [pFSH]) have only trace amounts of LH that remain as contaminants from the purification process $(10,14)$.

clomiphene citrate Previously considered an antiestrogen, clomiphene citrate recently was reclassified as a selective estrogen receptor modulator.(11) It is known to be both an estrogen agonist and antagonist; however, its agonist properties manifest only when endogenous estrogen levels are extremely low. In general, its antagonistic effects prevail. 
Clear indications for clomiphene citrate use include anovulation or oligo-ovulation and luteal phase deficiency. Clomiphene citrate has also been used in women with unexplained infertility, although limited data exist to justify such use.

An estimated $25 \%$ of female infertility has been attributed to anovulation or oligo-ovulation.(5) Clomiphene citrate is primarily used in group II disorders.(7) This particular group includes women with anovulation or oligo-ovulation with normal basal levels of endogenous estradiol, including women with polycystic ovary syndrome (PCOS),(12).

Regimens combining clomiphene citrate with other agents (eg, insulin-sensitizing agents, glucocorticoids, and exogenous gonadotropins) may be effective when treatment with clomiphene citrate alone fails to induce ovulation.

Pregnancies and live birthes are achieved more effectivally and faster after OI with low dose FSH than with CC (13).

The aim of this work is compare the effect of starting with gonadotropins versus clomiphene citrate in anovulatory women on time and rate of ovulation and progress of follicular maturation

\section{Materials and Methods}

A case-control study include 40 patients anovulatory (regular and irregular cycles) and want pregnancy attend to outpatient clinic in Suez Canal University hospital.

\section{Inclusion criteria:}

1-male factor normal.

\section{2-FSH and LH normal}

3-seum midluteal phase progesteron on day 21 of a day 28 day cycle (or 7 days before next period if cycle $>28$ days. Abnormal $(10 \mathrm{ng} / \mathrm{ml})$ was taken arbitrarily as the cut-off level of discrimination between 'adequate' and 'inadequate' corpus luteum function and $<3 \mathrm{ng} / \mathrm{ml}$ anovulation

4-Normal TSH and prolactine.
The cases were divided into two groups as:

- G1 20 patients starting with cc in $2^{\text {nd }}$ day of cycle $100 \mathrm{mg}$ daily for 5 days then complete from $7^{\text {th }}$ day with FSH till dominant follicle DF $18 \mathrm{~mm}$ or more.

- G2 20 patients starting with FSH 75 IU in $2^{\text {nd }}$ day of cycle for 4 days then complete from $6^{\text {th }}$ day with cc till dominant follicle DF $18 \mathrm{~mm}$ or more. adjusted depending on the estradiol and ultrasound response. With the progress of follicular maturation, Folliculometry and E2 when DF 18 or more.

\section{Statistical analysis:}

SPSS statistical software was used applying appropriate statistical method. Data are presented as mean $\pm \mathrm{SD}$. Differences between two groups were assessed by the Student's paired t test, chi square test Comparison among the two groups was performed by one way analysis of variance. Chi square test was also used. $\mathrm{P}$ value $<0.05$ was considered significant and $\mathrm{P}$ value $<0.01$ is considered highly significant.

\section{Results}

-There was significant difference in ovulation in both groups:

G2 more significant in ovulatory response and ovulatory rate than $\mathrm{G} 1$ as The ovulation rates in G2 were $83 \%$, whereas in G1, the ovulation rates were $65 \%(\mathrm{p}<0.05)$

-There was significant difference in E2 level in G2 than in G1 as preovulatory E2 levels (about $300 \mathrm{pg} / \mathrm{mL}$ or $900 \mathrm{pmol} / \mathrm{L}$ ) was achieved in $\mathrm{G} 2$ and less in G1 
Int. J. Curr. Res. Med. Sci. (2018). 4(5): 45-50

Table (1) Comparison between G1 and G2 in their hormonal profile:

\begin{tabular}{|l|c|c|c|c|c|}
\hline Group/mean,SD & FSH & LH & PROGESTERON & TSH & PROLACTINE \\
\hline G1 & $4.1 \pm 2.6$ & $3.5 \pm 1.74$ & $1.7 \pm 1.1$ & $1.5 \pm 2.5$ & $10.5 \pm 3.5$ \\
\hline G2 & $3.4 \pm 2.4$ & $4.3 \pm 1.4$ & $1.6 \pm 1.2$ & $1.5 \pm 2.8$ & $12.5 \pm 2.8$ \\
\hline Chi square & 0.076 & 0.15 & 0.023 & 0.026 & 0.026 \\
\hline P value & 0.78 & 0.69 & 0.85 & 0.87 & 0.87 \\
\hline
\end{tabular}

Table (2) Comparison between group G1 and G2 in E2

\begin{tabular}{|l|c|}
\hline \multicolumn{1}{|c|}{ Group/mean,SD } & E2 \\
\hline G1 & $135 \pm 200$ \\
\hline G2 & $300 \pm 600$ \\
\hline Chi square & 5.95 \\
\hline P value & $0.05^{*}$ \\
\hline
\end{tabular}

$P$ value $<0.05$ is considered significant*

$P$ value $<0.01$ is considered highly significant**

Table (3) Comparison between group G1 and G2 in ovulation rates by folliculometry

\begin{tabular}{|l|c|}
\hline \multicolumn{1}{|c|}{ Group/mean,SD } & ovulation rates \\
\hline G1 & $65 \%$ \\
\hline G2 & $83 \%$, \\
\hline Chi square & 4.8 \\
\hline P value & $0.05 *$ \\
\hline P value $<0.05$ is considered significant* & \\
\hline
\end{tabular}

$\mathrm{P}$ value $<0.05$ is considered significant*

Table (4) Comparison between group G1 and G2 in time of ovulation by folliculometry

\begin{tabular}{|l|c|}
\hline \multicolumn{1}{|c|}{ Group/mean, SD } & Early ovulation \\
\hline G1 & $10 \%$ \\
\hline G2 & $97 \%$ \\
\hline Chi square & 22.8 \\
\hline P value & $0.0001^{* *}$ \\
\hline P value $<0.01$ is considered highly significant $* *$ \\
\hline
\end{tabular}

\section{Discussion}

NICE clinical guidelines(1)found that there were significantly more clinical pregnancies after FSH compared with metformin plus clomifene citrate .

The use of FSH is well established for the induction of ovulation in anovulatory women and for the induction of multiple oocyte development in preparation for various assisted reproductive technologies.

And this was reported in this study as ovulation response and the ovulation rates in $\mathrm{G} 2$ were $83 \%$, whereas in $\mathrm{G} 1$, the ovulation rates were $65 \%$ ( $\mathrm{p}<$ $0.05)$

And E2 was higher in G2 than G1. 
Also Al-Inany et al 2016 Pregnancies and live birthes are achieved more effectively and faster after OI with low dose FSH than with CC.

and also in this study ovulatory response was more higher and faster in G2 than G1 as, the ovulation rates were significant $(\mathrm{p}<0.05)$ and early ovulation is considered highly significant in $\mathrm{G} 2$ than $\mathrm{G} 1$ ( $\mathrm{p}<0.0001)$.

Also it was found that a cost effective regimen to start with FSH and continue with clomiphene citrate as number of FSH amp in G2 less than G1.

Carr, et al (5) found that clomiphene citrate, interrupting the negative feedback that estrogen normally produces. Clomiphene citrate administration leads to depletion of estrogen receptors at the level of the pituitary and hypothalamus, interrupting the negative feedback that estrogen normally produces. As a result, $\mathrm{GnRH}$ secretion is improved and stimulates pituitary production of follicle-stimulating hormone $(\mathrm{FSH})$, which in turn drives follicular growth and maturation with emergence of 1 or more dominant follicles(11).

And as reported by Laurel, et al (10):

- FSH is necessary in the early phase of the cycle to recruit and select the follicle.

-Both FSH and LH are necessary for growth and maturation of the follicle.

-The daily increase in the follicular diameter in the active phase is by 1.5 to $2 \mathrm{~mm} /$ day.

So starting with FSH more effective to induce follicular growth and maturation faster and better than starting with clomiphene citrate and this was reported in this study as early ovulation is considered highly significant in $\mathrm{G} 2$ than $\mathrm{G} 1$ ( $\mathrm{p}$ $<0.0001)$.

\section{Conclusion}

The results suggest that it is more effective to start with gonadotropins versus clomiphene citrate in anovulatory women on time and rate of ovulation and as a cost effective regimen.

\section{References}

1.NICE clinical guidelines: fertility assessment and treatment for people with fertility problems February 2013

2. World Health Organization. WHO Manual for the Standardized Investigation and Diagnosis of the Infertile Couple. Cambridge, United Kingdom: Cambridge University Press; 1993

3.Azziz R, Woods KS, Reyna R, Key TJ, Knochenhauer ES, Yildiz BO. The prevalence and features of the polycystic ovary syndrome in an unselected population. J Clin Endocrinol Metab. 2004;89(6):2745-2749.

4. Schriock ED, Jaffe RB: Induction of ovulation with gonadotropin-releasing hormone. Obstet Gynecol Surv. 41: 414, 1986

5. Carr SJ, Reid R: Ovulation induction with gonadotropin-releasing hormone $(\mathrm{GnRH})$. Semin Reprod Endocrinol 8: 174, 1990.

6. Coelingh Bennink HJT: Pulsatile administration of LHRH for induction of ovulation. In Shaw RW, Marshall JC (eds): LHRH and Its Analogues, pp 92-112. Toronto, Wright, 1989

7. Filicori M, Flamigni C, Merriggiola MC et al: Ovulation induction with pulsatile gonadotropin-releasing hormone: Technical modalities and clinical perspectives. Fertil Steril 56: 1, 1991.

8. Burger CW, Korsen TJM, Hompes PGA et al: Ovulation induction with pulsatile luteinizingreleasing hormone in women with clomiphene citrate-resistant polycystic ovary-like disease: Clinical results. Fertil Steril 1045: 46, 1986.

9. Kelly AC, Jewelewicz R: Alternate forms for ovulation induction in polycystic ovarian disease. Fertil Steril 54: 195, 1990

10.Laurel A. Stadtmauer, Abbaa Sarhan,E.Hakan Duran, HindBeydoun, et al. The impact of a gonadotropin-releasing hormone antagonist on gonadotropin ovulation induction cycles in women with polycystic ovary syndrome: a prospective randomized study. January 2011. Fertility and Sterility vol.95,Issue 1, page 216220.

11. Shelly W, Draper MW, Krishnan V, Wong M, Jaffe RB. Selective estrogen receptor modulators: an update on recent clinical findings. Obstet Gynecol Survey. 2008;63(3):163-181. 
12. Hughes E, Brown J, Collins JJ, Vanderkerchove P. Clomiphene citrate for unexplained subfertility in women. Cochrane Database Syst Rev. 2010;(1):CD000057.

13. Al-Inany et al 2016 Fertility and sterility

14. Schorge JO, Schaffer JI, Halvorson LM, Hoffman BL, Bradshaw KD, Cunningham FG.

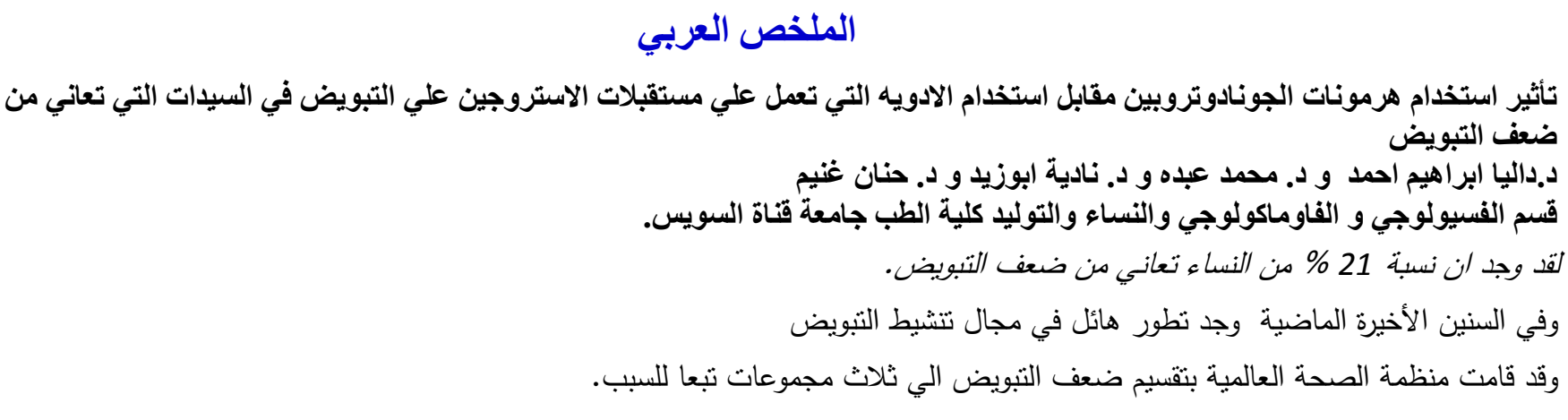

اكثرها انتثارا المجموعة الثانية وتمثل 85\% والتي يكون فيها ضعف التبويض ناتج عن اضطرابات في الهرمونات التي تفرز من الغذة النخامية متل مرضي تكيسات المبايض.

وهذا النوع من ضعف التبويض يستجيب الي هرمونات الجونادوتروبين والي الأدوية التي تعمل علي مستقبلات الاستروجين منل الكلوموفين سيترات.

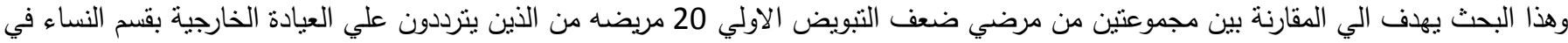

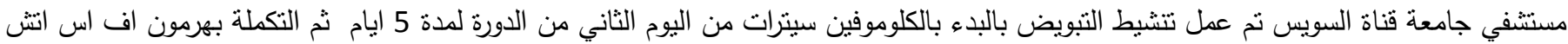

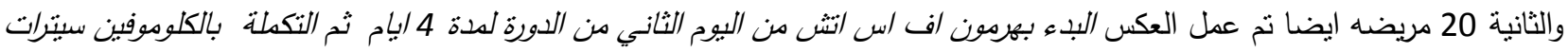
وتم قياس معدل حدوث التبويض واستجابة المبايض وايضا وقت حدوث التنبويض في كل مريضة عن طريق متابعة التنويض بالسونار وقياس هرمون الاستروجين. وقد وجد ان الاستجابة بمعدل اعلي في المجموعة الثانية اكثر من (0.05 م م) المجموعة الاولي الاني

وايضا حدوث التبويض اسرع في المجموعة الثانية من المجموعة الاولي (0.0001 م م) كما ان عدد الحقن المستخدمة اقل ولذا نستتنج ان البدء بالهرمون افضل في معدل نمو البويضة واسرع واقل تكلفة للمريضة.

\begin{tabular}{|c|l|}
\hline \multicolumn{2}{|c|}{ Access this Article in Online } \\
\hline Q & Website: \\
& www.ijcrims.com \\
\cline { 1 - 1 } & Subject: \\
Quick Response Code & \\
\hline
\end{tabular}

How to cite this article:

Dalia Ibrahim, Mohamed Abdo, Nadia Abozied and Hanan Ghoniem. (2018). Effect of gonadotropins versus a selective estrogen receptor modulator on ovulation in anovulatory women. Int. J. Curr. Res. Med. Sci. 4(5): 45-50.

DOI: http://dx.doi.org/10.22192/ijcrms.2018.04.05.007 